\title{
Efficacy of citric acid on periodontal disease.
}

\author{
Ehan Abdulhadi Al-Sharifi ${ }^{1 *}$, Noor Alkaisy ${ }^{1}$, Asia Abed Al-Mahmood ${ }^{2}$ \\ ${ }^{1}$ College of Dentistry, Ibn Sina University of Medical and Pharmaceutical Sciences, Iraq \\ ${ }^{2}$ College of Dentistry, Al-Iraqia University, Iraq
}

\begin{abstract}
Background: The single most common primary etiological factor in periodontal disease is a bacterial plaque. Periodontitis affected root surface undergo physical and chemical damage that makes them a poor base for attachment and proliferation of fibroblast. Citric acid has a bacteriostatic effect and can cause root biomodification to remove the smear layer and expose root collagen fiber.

Method: Forty swabs were taken from patients having periodontitis attended Al-Furat General hospital/ Dentistry department from August to November 2018. Each swab was taken around the tooth before and after tooth extraction. These swabs were cultured on blood and MacConkey agar plates. Different types of bacteria were isolated in the area of periodontitis. In addition, different concentrations of citric acid solution $(0.3,0.4,0.5,0.75$ and $1 \mathrm{~g} / \mathrm{ml})$ were prepared and added to bacterial growth, and then the minimum inhibition zone was determined.

Results: Four types of bacteria were isolated from the patient in the area of periodontitis: Streptococcus mutans, Escherichia coli, Staphylococcus aureus and anaerobic bacteria. No bacteria were isolated in the area after tooth extraction. Concentrations of the citric acid that showed the zone of inhibition on bacterial growth were $0.4,0.5,0.75$, and $1 \mathrm{~g} / \mathrm{ml}$.

Conclusion: Streptococcus mutans appeared at a high level in patients with periodontitis. The concentration of citric acid $(0.4,0.5,0.75,1 \mathrm{~g} / \mathrm{ml})$ was proved to inhibit the growth of bacteria in the smear area of diseased teeth; therefore, could be suggested to be used as a root conditioning agent.
\end{abstract}

Keywords: Periodontal disease, Streptococccus mutans, Citric acid.

Accepted on March 21, 2019

\section{Introduction}

Citric acid has the ability to change the surfaces of the treated root by removing the smear layer, expose the dentinal tubules and making the tubules appear wider and with funnel-shaped orifices $[1,2]$. In periodontal disease, exposed cementum show accumulation of plaque and calculus on root surface with loss of collagen cross banding [3]. Citric acid partially exposes the collagen from radicular dentin that improves fibrin linkage and inhibits epithelial down growth to stimulate fibrous attachment and migration [4], it also acts as a potent antibacterial agent [2]. Periodontal diseases are a bacterial infection that destroys the gum and the bone that hold the teeth in the mouth. Periodontal disease can affect one tooth or many teeth. The mean cause of periodontal disease is a bacterial plaque. Periodontal disease is multifactorial; tobacco, hormonal change, genetic, stress, some medications, destructive habit, poor nutrition, systemic diseases, and chronic periodontitis is the condition that results in inflammation within the soft tissue surrounding the teeth causing progressive attachment and bone loss. Demineralization of dental root surface exposed to periodontal disease is widely employed in periodontology to recreate a biologically active substrate for cell reattachment and cementogenesis [5]. When citric acid demineralization was combined with growth factors on disease human root surface, increased proliferation of the fibroblast for human periodontal ligament was produced in culture [6]. The first step in the physiological mechanism of bone remodeling is demineralization by local production of acid by the osteoclasts [7]. Studies had shown citric acid can cause collagen fiber exposure which augments the connective tissue attachment to the root surface [8]. The aim of the study is to estimate the effect of citric acid on different bacterial growth caused by periodontitis.

\section{Materials and Methods}

\section{Samples collection}

Forty swabs were taken from patients with periodontal disease attended Al-Furat General Hospital/Dentistry Department from August to November 2018. The patients had been diagnosed by a special dentist. Twenty swabs were taken from the area around the tooth before extract, and twenty swabs after tooth extraction. These swabs were cultured on the blood and 
Maconkey agar plates and put in the incubator at $37^{\circ} \mathrm{C}$ for 24 hours for each culture.

\section{Bacteria identification}

The diagnosis of Staphylococcus aureus was confirmed, by doing subcultures on mannitol salt agar plate at $37^{\circ} \mathrm{C}$ for 24 hours. In addition, diagnosis of Streptococcus mutans was confirmed by doing subcultures of the growth on Tryptic Soya Broth at $37^{\circ} \mathrm{C}$ for 24 hours. Moreover, diagnosis of Escherichia coli was confirmed by doing subculture on the endoagar which appeared red color because it is lactose fermenter.

\section{Preparation of citric acid stock solution}

Ten grams of citric acid were added to $100 \mathrm{ml}$ of distilled water in a sterilized conical flask. Stock solution was prepared to get the required concentrations of $0.3,0.4,0.5,0.75$ and $1 \mathrm{~g} / \mathrm{ml}$.

\section{Minimum inhibitory concentration determination}

Minimum inhibition concentration was determined for bacterial cultures after the addition of different concentration of the citric acid.

\section{Data analysis}

Data were expressed as (mean \pm standard deviation) with ( $\mathrm{p}$ $<0.05)$ to be considered as significant. Unpaired t-test was used to camper the concentrations of citric acid and minimum inhibition zone.

\section{Results}

A total number of forty (40) swabs were taken from the periodontal area of twenty patients with periodontitis (before and after tooth extraction) respectively. Numerous types of microorganisms were isolated from the swabs taken before extraction of teeth but there were no microorganisms detected after teeth extraction.

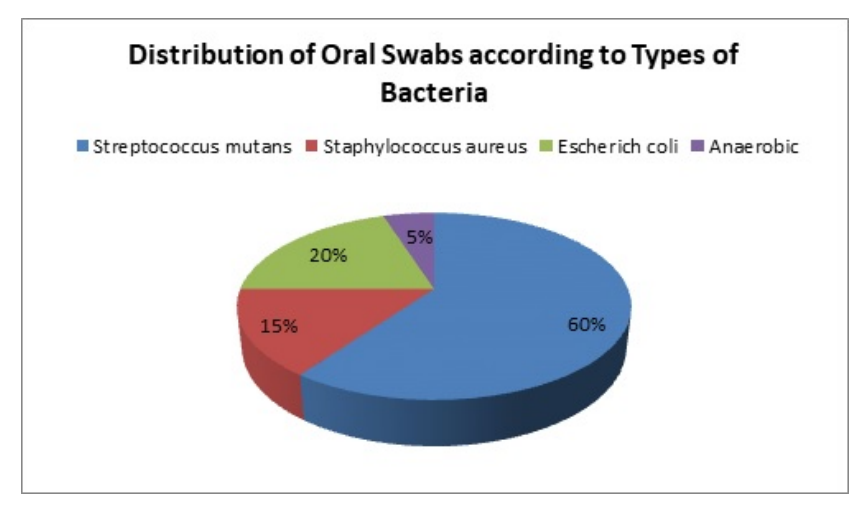

Figure1. Distribution of oral swabs according to types of bacteria.

Streptococcus mutans growth was detected significantly in higher count compared with other species (Figure 1) followed by Escherichia coli that were detected in limited frequency, whereas Staphylococcus aureus strain was detected in a low count and finally the anaerobic bacteria present in the lowest frequency. Citric acid was evaluated as a bacteriostatic agent (in vitro) at concentrations of $(0.4,0.5,0.75,1 \mathrm{~g} / \mathrm{ml}$ ) respectively while it did not show any activity at concentration $0.3 \mathrm{~g} / \mathrm{ml}$ as shown in Figure 2.

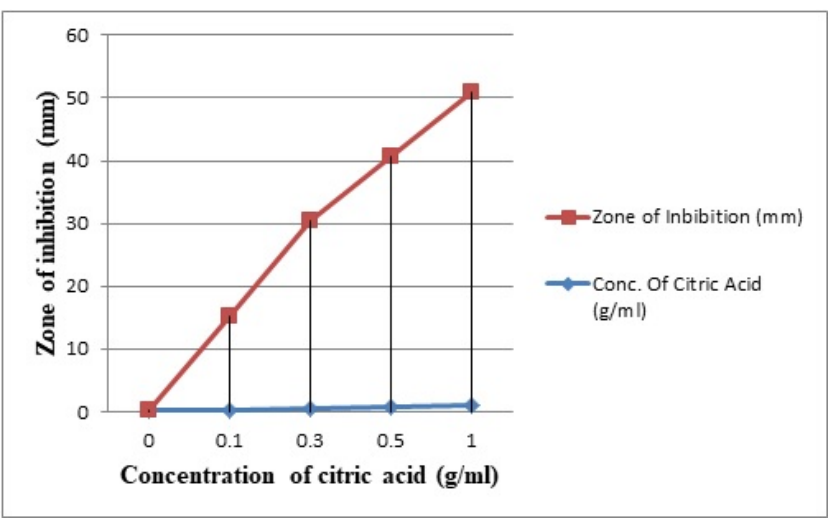

Figure 2. The relationship between the concentration of citric acid and the zone of inhibition.

Data presented as citric acid concentration $(\mathrm{g} / \mathrm{ml})$ mean $\pm \mathrm{SD}$ $(0.59 \pm 0.283)$ and inhibition zone $(\mathrm{mm})$ mean \pm SD $(27 \pm$ 19.87). Unpaired t-test was used to compare the concentration of citric acid and inhibition zone variables; $p<0.05$ to be considered as significant.

\section{Discussion}

Periodontal disease is the most frequent reason for teeth extraction in patients over 40 years of age [9]. Identification of the microorganisms responsible for periodontal pathology and their relation to periodontal inflammation in addition to their accurate management are some of the goals of recent dental, as well as general medical research. Streptococcus mutans is an aciduric Gram positive bacterium which may be naturally found in saliva and dental plaque. In the present study, Streptococcus mutans strain was isolated from swabs taken from the periodontal area of chronic periodontitis patients before teeth extraction. A higher presence of $S$. mutans (Figure 1) in patients with chronic moderate or severe periodontitis before extraction of teeth might derive from a lower oxygen tension within the periodontal pockets [10]. This is in accordance to studies by Cortelli et al. [11] and Dani et al. [12] who found a high proportion of this microorganism in subgingival plaque samples of chronic periodontitis patients.

While in contradiction to this study, the study of Koll-Klais et al. [13] who discover high proportions of these strains in healthy subjects, indicating that they could help in maintaining micro-ecological homeostasis in the oral cavity. The variation in results could be attributed to the differences in the sampling technique whether to be saliva (stimulated or unstimulated) or swabs on a subgingival plaque in addition to the diversity of oral biofilm formation. Staphylococcus aureus shows the low prevalence rate in the present study (Figure 1), this is in agreement with Colombo et al. [14] in a study who found that the proportion of $S$. aureus was relatively low in periodontitis. Zinsli et al. [15] reported high levels of $S$. aureus (>105 cells) 
in subgingival samples of chronic and aggressive periodontitis patients. This discrepancy might be due to different techniques used in previous studies, which did not include epithelial cell sample.

Among pathogens related to periodontitis is Escherichia coli, which detected in the current study in subgingival plaque area, accordingly the study by Amel et al. [16] had shown that $E$. coli was grown in both chronic and aggressive periodontitis; while Betancourth et al. [17] showed that micro-organisms of the family Enterobacteriaceae (gram-negative rods) were considered as unusual in periodontitis patients.

Findings of anaerobic culture on advanced and chronic periodontitis were detected in the lowest frequency in this study (Figure 1), which might be due to variations in species responsible for disease progression; further, additional species need to be detected using molecular methods which could be more related to periodontitis pathology [18]. The investigators stated that some of the subgingival pathogens disappear from the oral cavity after being edentulous, and do not reappear even when hard surfaces were provided such as dentures [19]. This is in agreement with our findings that the microorganisms didn't appear after tooth extraction probably due to that the elimination of the subgingival niches by extraction of teeth could initiate a spontaneous disappearance of periopathogens; while the study of Van Assche et al. [20] contradict the hypothesis of a spontaneous eradication of all periopathogens after full extraction of teeth and there was only a significant reduction. It has been shown that citric acid promotes dentin reattachment and regeneration by its antibacterial effect and enhances initial clot stabilization. Citric acid has been shown to produce more clot stabilization on the dentin surface than other solutions [21].

Several in vitro [22] and in vivo studies [23,24] have been used in the conditioning of the root surface using different methods and materials as an alternative treatment to scaling and root planning in the regenerative process for periodontitis.

Various chemical agents have been used in root conditioning with different composition, concentration, time and mode of application of the conditioning agent in addition to the $\mathrm{pH}$ of the material used; among them is citric acid. [25,26].

In our study, the effect of citric acid as a bacteriostatic agent (in vitro) was detected at concentrations of $(0.4,0.5,0.75,1 \mathrm{~g} / \mathrm{ml})$, (Figure 2) so that the smear layer could be removed effectively by the presence of inhibition zone this is in agreement with the study of [26], this is mainly referred to the potential acidity and its dissolution and etching power on both organic and inorganic precipitates. But citric acid at a concentration of $(0.3) \mathrm{g} / \mathrm{ml}$ had no effects on periodontal pathogens by the absence of the inhibition zone.

The study of [27] reported the use of chewing gum containing citric acid would reduce the periodontal pathogens in the oral cavity, through increased salivary flow and increase in the concentration of salivary human beta-defensins with potent antimicrobial activity.
Others used lemon fruit juice as a bacteriostatic oral rinsing agent [28]. As lemon juice contains abundant citric acid in its composition [29].

\section{Conclusion}

Elevated Streptococcus mutans levels appear directly coassociated with untreated periodontal disease. Concentrations of citric acid of $(0.4,0.5,0.75,1) \mathrm{g} / \mathrm{ml}$ were proved to be effective in removing smear layer of the periodontal area for teeth with periodontitis, so it could be suggested to be used as a root conditioning agent. Attention should be given to periodontitis patients who may harbor pathogenic microorganisms in the oral cavity so as to decrease the risk of systemic infections.

\section{Conflicts of Interest}

The authors declare that there is no conflict of interests regarding the publication of this article.

\section{References}

1. Wen CR, Caffesse RG, Morrison EC, Nasjleti CE, Parikh UK. In Vitro Effects of Citric Acid Application Techniques on Dentin Surfaces. J Periodontol 1992; 63:883-889.

2. Polson AM, Hanes PJ. Cell and fiber attachment to demoralized dentin A comparison between normal and periodontitis-affected root surfaces. J Clin Periodontol 1987; 14:357-465.

3. Lasho DJ, O'Leary TJ, Kafrawy AH. A scanning electron microscope study of the effects of various agents on instrumented periodontally involved root surfaces. J Periodontol 1983; 54:210-220.

4. Rompen EH, Goffinet GH, Nusgens B. Human Periodontal Ligament Fibroblast Behavior on Chemically Conditioned Dentine: An In Vitro Study. J Periodontol 1999; 70:1144-1152.

5. Mariotti A. Efficacy of Chemical Root Surface Modifiers in the Treatment of Periodontal Disease. A Systematic Review. Ann Periodontol 2003; 8:205-226.

6. Sant'Ana ACP, Marques MM, Barroso EC, Passanezi E, de Rezende MLR. Effects of TGF- $\beta 1$, PDGF-BB, and IGF-1 on the Rate of Proliferation and Adhesion of a Periodontal Ligament Cell Lineage In Vitro. J Periodontol 2007; 78:2007-2017.

7. Stahl SS. Periodontal surgery: biologic basis and technique. Springfield: Thomas; 1976.

8. Bergenholtz A, Babay N. Scanning electron microscopy of the root surface texture of extracted periodontally diseased teeth following various etching and chelating regimens. Int J Periodontics Restorative Dent 1998; 18:171-179.

9. Hatem AE. Epidemiology and Risk Factors of Periodontal Disease. In: Periodontal Diseases-A Clinician's Guide. InTech 2012. 
10. De Soete M, Dekeyser C, Pauwels M, Teughels W, Van Steenberghe D, Quirynen M. Increase in cariogenic bacteria after initial periodontal therapy. J Dent Res 2005; 84:48-53.

11. Cortelli SC, Cortelli JR, Aquino DR, Holzhausen M, Franco GCN, Costa FO, Fine D. Clinical status and detection of periodontopathogens and Streptococcus mutans in children with high levels of supragingival biofilm. Braz Oral Res 2009; 23:313-318.

12. Dani S, Prabhu A, Chaitra K, Desai N, Patil S, Rajeev R. Assessment of Streptococcus mutans in healthy versus gingivitis and chronic periodontitis: A clinicomicrobiological study. Contemp Clin Dent 2016; 7:529.

13. Kõll-Klais P, Mändar R, Leibur E, Mikelsaar M. Oral microbial ecology in chronic periodontitis and periodontal health. Microb Ecol Health Dis 2005; 17:146-155.

14. Colombo AV, Barbosa GM, Higashi D, di Micheli G, Rodrigues PH, Simionato MRL. Quantitative detection of Staphylococcus aureus, Enterococcus faecalis and Pseudomonas aeruginosa in human oral epithelial cells from subjects with periodontitis and periodontal health. J Med Microbiol 2013; 62:1592-1600.

15. Fritschi BZ, Albert-Kiszely A, Persson GR. Staphylococcus aureus and other bacteria in untreated periodontitis. J Dent Res 2008; 87:589-593.

16. Amel Y, Bouziane D, Leila M, Ahmed B. Microbiological study of periodontitis in the West of Algeria. World J Med Sci 2010; 5:2007-2010.

17. Bact MB, Arce R, Botero J, Mag JA, Mat CCL, Conterares A. Unusual microorganisms in gingival sulcus and periodontal pockets. Colomb Med 2006; 37:6-14.

18. Wade WG. The oral microbiome in health and disease. Pharmacol Res 2013; 69:137-143.

19. Kononen E, Paju S, Pussinen PJ, Hyvonen M, Di Tella P, Suominen-Taipale L, Knuuttila M. Population-based study of salivary carriage of periodontal pathogens in adults. J Clin Microbiol 2007; 45:2446-2451.

20. Van Assche N, Van Essche M, Pauwels M, Teughels W, Quirynen M. Do periodontopathogens disappear after fullmouth tooth extraction? J Clin Periodontol 2009; 36:1043-1047.

21. Leite FRM, Sampaio JEC, Zandim DL, Dantas AAR, Leite ERM, Leite AA. Influence of root-surface conditioning with acid and chelating agents on clot stabilization. Quintessence Int (Berl) 2010; 41:341-349.

22. Fardal O, Lowenberg BF. A Quantitative Analysis of the Migration, Attachment, and Orientation of Human Gingival Fibroblasts to Human Dental Root Surfaces in vitro. J Periodontol 1990; 61:529-535.

23. Cole RT, Crigger M, Bogle G, Egelberg J, Selvig KA. Connective tissue regeneration to periodontally diseased teeth: A histological study. J Periodontal Res 1980; 15:1-9.

24. Crigger M, Renvert S, Bogle G. The effect of topical citric acid application on surgically exposed periodontal attachment. J Periodontal Res 1983; 18:303-305.

25. Ruggeri A, Prati C, Mazzoni A, Nucci C, Di Lenarda R, Mazzotti G, Breschi L. Effects of citric acid and EDTA conditioning on exposed root dentin: An immunohistochemical analysis of collagen and proteoglycans. Arch Oral Biol 2007; 52:1-8.

26. Cavassim R, Leite FRM, Zandim DL, Dantas AAR, Rached RSGA, Sampaio JEC. Influence of concentration, time and method of application of citric acid and sodium citrate in root conditioning. J Appl Oral Sci 2012; 20:376-383.

27. Nikawa H, Igarashi S, Takasu O, Tataka H, Harano F, Shinohara S, Makihira S, Takemoto T, Murayama T, Satoda T, Amano H, Kurihara H. Chewing Gum Containing Citric Acid Reduces the Burden of Periodontal Pathogens. Open Food Sci J 2008; 2:29-37.

28. Kato Y, Otsubo K, Furuya R, Suemichi Y, Nagayama C. Bacteriostatic Effect of Lemon Fruit Juice: It's Potential as an Oral Rinsing Agent. J Oral Hyg Heal 2018; 6:1-3.

29. Penniston KL, Nakada SY, Holmes RP, Assimos DG. Quantitative assessment of citric acid in lemon juice, lime juice, and commercially-available fruit juice products. J Endourol 2008; 22:567-570.

\section{*Correspondence to}

Ehan Abdulhadi Al-Sharifi

College of Dentistry

Ibn Sina University of Medical and Pharmaceutical Sciences Iraq 